\title{
The complexity of a hybrid life: Female immigrants in France and Germany in search of their own identity
}

Anneke V. Seynnaeve

West Virginia University

Follow this and additional works at: https://researchrepository.wvu.edu/etd

\section{Recommended Citation}

Seynnaeve, Anneke V., "The complexity of a hybrid life: Female immigrants in France and Germany in search of their own identity" (2006). Graduate Theses, Dissertations, and Problem Reports. 714.

https://researchrepository.wvu.edu/etd/714

This Thesis is protected by copyright and/or related rights. It has been brought to you by the The Research Repository @ WVU with permission from the rights-holder(s). You are free to use this Thesis in any way that is permitted by the copyright and related rights legislation that applies to your use. For other uses you must obtain permission from the rights-holder(s) directly, unless additional rights are indicated by a Creative Commons license in the record and/ or on the work itself. This Thesis has been accepted for inclusion in WVU Graduate Theses, Dissertations, and Problem Reports collection by an authorized administrator of The Research Repository @ WVU. For more information, please contact researchrepository@mail.wvu.edu. 
The Complexity of a Hybrid Life:

Female Immigrants in France and Germany in Search of Their Own Identity

Anneke V. Seynnaeve

Thesis submitted to the College of Arts and Sciences at West Virginia University in partial fulfillment of the requirements

for the degree of

Master of Arts

in

Foreign Languages

Valérie Lastinger, Ph.D., Chair

Twyla Meding, Ph.D.

Cynthia Chalupa, Ph.D.

Copyright @ 2006 Morgantown West Virginia University

Key words: Female immigrants, France and Germany, Hybrid Life, Own Identity 


\title{
ABSTRACT \\ The Complexity of a Hybrid Life: \\ Female Immigrants in France and Germany in Search of Their Own Identity
}

\begin{abstract}
Anneke V. Seynnaeve
Female Muslim immigrants in France and Germany are increasingly experiencing challenges integrating into Western lifestyle. They have to adjust to occidental communities in which they try to incorporate their own traditions and values. They experience feelings of simultaneous belonging and rejection at the same time. My research concentrated on the adaptation of Muslim Women in Germany and France. Although many similarities exist between the French and German immigrant groups, it was necessary to examine each one separately. In order to understand Islamic female immigrants' quest for a new identity, it was beneficial not only to address the sociocultural aspects of their lives, but also to examine the great influence immigrant literature and mass media have on them. I hope academic endeavors such as mine will be a step in the direction of a society that will be more aware of racism and sexism.
\end{abstract}




\section{ACKNOWLEDGMENT}

My deep thanks go to Prof. Valérie Lastinger, my thesis director and very dear friend, who has guided me through every step of the process with unflagging enthusiasm. She was always available and offered excellent ideas for my research.

I also want to thank very strongly Prof. T. Meding and Prof. C. Chalupa for the valuable advice and information they gave me during the writing of my thesis.

I am grateful to my niece Anneleen Masschelein, who read an early version of my thesis and whose commented on it very positively.

My heartfelt thanks to Weena Gaulin who has been very helpful in formatting my thesis and who made me persevere.

I would not have been able to write this paper without the constant encouragement from my family. My deepest love goes to my husband Johan and my children Katrijn and Carl. They gave me perspective, patience and they always believed in my work. 
Nooit de moed opgeven $\mathrm{Ne}$ perds jamais courage Never lose courage Nie den Mut verlieren

Eugène Mattelaer

To Johan

Katrijn and Sam

Carl and Bre 
TABLE OF CONTENTS

Abstract ii

Acknowledgment iii

Table of Contents V

Introduction 1 Chapter One: Fundamental Traditional Issues Concerning Islamic Women in the Western World 5

A. Tradition, Religious Laws, and Females

1. Marriage and Polygamy …………………………………...............

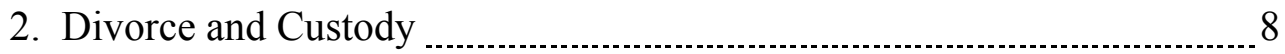

3. Male Dominance and Honor …………………………………......

4. Head scarf, Veil or "Hijab" .................................................................... 13

B. Language Barriers and Education $\ldots \ldots \ldots \ldots$

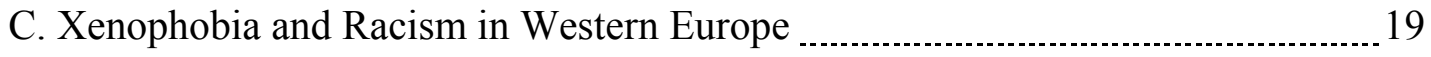

D. Dual Citizenship and Immigration Policies in France and Germany ..................2 21

Chapter Two: Identity Predicaments for Beurettes in France and Female

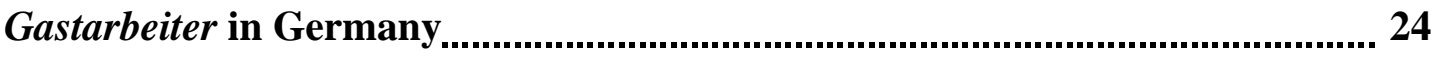

A. Reflections on and Reactions to the Term Beur ................................................ 25

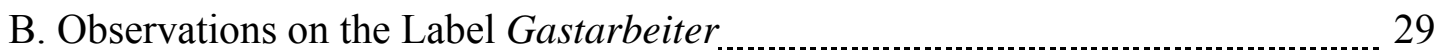

C. Similar Predicaments that Second Generation Females Encounter in Beur's Story and Gegen die Wand 
Chapter Three: Living in a Hybrid World: Literary Women Speak up

.43

A. The Faith of Female Turkish Immigrants in Germany Seen through Steinhardt's

Writings

B. L. Sebbar's Writings: Algerian and French Influences are Prevalent in her Literary

Works 52

Conclusion 58

Works Cited 64 


\section{INTRODUCTION}

Muslim immigrants in France and Germany are increasingly experiencing many challenges in adapting to Western lifestyle. Both countries recruited foreign workers to be laborers during the post World War II era. The German Muslim population, mostly of Turkish origin, came as Gastarbeiter after World War II, while the majority of French Muslims came from former colonies such as Algeria and Morocco. Although these immigrants have different backgrounds, they have to adapt to similar occidental communities in which they try to incorporate their own traditions and values. They share feelings of alienation and marginalization, but after the second generation takes root, solidarity develops between Muslim groups across the borders of Western Europe. Female Muslim immigrants have to endure specific hardships and difficulties that make their search for identity even more arduous than that of their male counterparts. They experience feelings of simultaneous belonging and rejection at the same time. My aim is to articulate the findings of my research in the area of the adaptation of Muslim Women in Western Europe with the main focus on Germany and France. From the second generation on there has been a significant increase of immigrant women whose everyday life is still influenced by Islamic culture in Western Europe, although they are more westernized in many other ways. I will use the term Muslim women or Islamic women to refer to women in that group. ${ }^{1}$ William Edmiston and Annie Duménil point out that since the terrorist attacks on Sept 11, 2001 the terms musulman, fondamentaliste, and

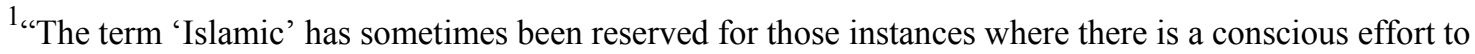
reflect the fundamental principles and ideals of Islam interpreted in a relatively restrictive way. In this usage, for example, a 'Muslim state' is a state where the majority of the people are Muslim, while an 'Islamic state' would be one in which there is a formal program of implementation of the regulations and ideals of Islam." (Encyclopedia of Islam and the Muslim world 360)
} 
islamiste are being confused with the militant Islamic groups who want a strict application of Islam and who use this religious label as a shield to justify their terrorist activities (195). For the Western media the term Islamism can have a pejorative meaning and it seen as a political movement:

In the aftermath of the September 11, 2001 attacks, Islamism, along with other political movements inspired by Islam gained increased attention in the Western media. The media often confuses the term Islamism with related terms such as Islam, fundamentalism, militant Islam and Wahhabism. Although the groups and individuals representing these are not mutually exclusive, within academia, each term does not have a distinct definition. Some Islamist groups have been implicated in terrorism and have become targets in the War on Terrorism (nationmaster.com).

In order to gain a better understanding of these Muslim women and they challenges they face, I will look at the patriarchal cultural background with regard to specific laws that govern different areas of the lives of these women: how they are affected by tradition, religion, and notions of honor and male dominance from their native culture. On a broader spectrum, I wish to address issues such as language barriers, education, racism, xenophobia, and dual citizenship. These topics will always be examined in the context of the impact they have on women. 
Although many similarities exist between the French and German immigrant groups, it will be necessary to examine each one separately. I will analyze the French of Maghrebi ${ }^{2}$ origin, also called "les Beurs" and the German "Gastarbeiter" of Turkish origin. Both expressions can have negative connotations and have to be used with great care.

In order to understand Islamic female immigrants' quest for a new identity, it will be beneficial not only to address the socio-cultural aspects of their lives, but also to examine the great influence immigrant literature and mass media have on them. The literary world of Saliha Scheinhardt and Leila Sebbar, who both bear witness through their own experience and writings, gives us insights into how women struggle for their own independence. Despite the fact that it is clear that women writers of Muslim backgrounds are making a key contribution to contemporary European literature, they still have to fight for their literary status.

After having examined the conflict and hardships that this particular group endures, it will become apparent that those problems will not be solved in the short term. Ultra right-wing political parties such as "neo-fascists" and "radical Islamists" are creating a world of fear and xenophobia. Recent violence became prevalent in Amsterdam, for example with the shooting of Theo Van Gogh - grandson of the famous Dutch painter - in November 2004. His murder shows that in these multicultural societies there exist great inequalities in matters of race, religion and gender. As I argue, there is solidarity between those heterogeneous Muslims groups that needs to be extended to the native population. It is the duty of today's European Community to accept all of its

\footnotetext{
${ }^{2}$ Maghrebi=adjective for the inhabitants of the North African countries, west of Egypt (Morocco, Algeria, Tunisia). Maghreb is the Arabic word for west.
} 
citizens. The attainment of equality is particularly crucial for Muslim immigrant women. It is also imperative that Muslim society abide by Western rules in the Western countries that they choose to immigrate to. I hope that academic endeavors such as mine will be a step in the direction of a society that will be more aware of racism and sexism. 


\section{CHAPTER ONE:}

\section{FUNDAMENTAL TRADITIONAL ISSUES CONCERNING ISLAMIC WOMEN IN THE WESTERN WORLD}

According to Garbi Schmidt, many studies both in The United States and Europe have shown that young, well-educated Muslim immigrants are increasingly in favor of reformation of Islamic traditions and are consciously exposing their Islamic faith (32). Furthermore, she explains: "Although most of my informants stated that Islam was a part of their upbringing and an integrated part of family life, they just as frequently stated that the Islam that they pursue is a-cultural, pure and progressive; Islam as it truly was and is supposed to be" (37).

In order for second and third generation Turkish immigrants to find a stability in their new homeland, Nikola Tietze writes that the Islamic faith is becoming one of their fundamental anchors and resources. He claims: "le 'Croire', et les rites, les dogmes, les interdits qui en découlent grâce à l'inscription dans l'islam, deviennent un art de diriger la conduite et un moyen d'atteindre des objectifs dans la vie quoditienne" (258). [The ''Faith", its rites, its dogmas, and necessary prohibitions that Islam prescribes, are becoming an example of how one needs to behave in everyday life ${ }^{3}$. Since Muslim women are affected by those norms when living in their new homeland, it is essential to analyze some specific aspects and rules of the Islamic faith that pertain to them.

\footnotetext{
${ }^{3}$ All translations unless otherwise noted are mine
} 


\section{A. Tradition, Religious Laws, and Females.}

The Muslim faith has been passed down from generation to generation. The primary laws of this religion are written in the Qur'an - The Holy Book -, the Sharia The Divine Law- and the Hadith - collected works that record in detail what the Prophet Mohammed said and did. These legal sources have shaped Muslim tradition and continue to influence its values and ethics in everyday family life. Many commands give conflicting or ambiguous instructions, especially with regard to mothers and daughters. Leslie Adelson comments: "Whether women in Islam are seen as objects or subjects, as weak, inferior, and sinful or powerful, equal, and venerable depends greatly on how one interprets the sacred text of the Qur'an as well on the historical vicissitudes of Muslim societies" (223). The laws of Allah to which women are subjected in their homeland continue to have a decisive impact in their new surroundings. As already described in the introduction, the Islamic religion is based on a patriarchal class system. Badawi writes that: "both [men and women] have equal rights and claims on one another, except for one responsibility, that of leadership. This is a matter which is natural in any collective life and which is consistent with the nature of man" (8). He also quotes the Qur'an that states: "And they (women) have rights similar to those (of men) over them, and men are a degree above them" (Qur'an 2:228). Charis Waddy however, points out that "the traditional place of women in Islam is a high one" and according to the Holy Writings they are equal to men but they each have their own function (9). This would imply that everyone should be treated as equals. But many young Muslim women who are living in the Western world are struggling with the traditional interpretation of the Qur'an because they are taught from a young age that the Holy Book favors men. Such 
contradiction can often lead to psychological strain and there is a need for help in those communities. "Muslim Women's Meeting and Continuing Education Center in Cologne" is an example of a structured support where females can freely get psychological help and educational support. For instance, this organization offers extra courses to girls so that they can complete their schooling. Such centers are barred to men and are supported by public funds (Naggar 1).

\section{Marriage and Polygamy}

Waddy points out that traditional Muslim society is centered around family life. Children are taught to obey their parents and respect older people. Boys and girls are treated the same and every man in the household is obligated to protect his women relatives. A father is responsible for his daughters for the rest of his life (56-57). Islamic teachings concerning marriage differ for males and females. For immigrant females who come more and more in contact with Western culture and populations, inter-religious marriages can be a great challenge because they are not permitted. A man can marry a Christian or a Jewish woman, but a woman is not allowed to marry a man who is not a Muslim. Naïma, a young Algerian woman states in Françaises: "Dans la religion musulmane, l'homme peut épouser une juive, une catholique... Parce que c'est lui qui transmet le sang, la religion, la culture, bref les origines. Alors qu'une femme musulmane qui se marie avec un catholique, par exemple, s'intègre à la religion de son mari et ne transmet plus rien" (192). [In the Muslim religion a man can marry a Jewish or Catholic wife.... because it is he who will transmit the blood, religion, culture, in short the origins. Whereas when a Muslim women marries a Catholic for example, she has to follow her husband's religion and so no longer transmits anything]. Naïma would never 
consider marrying a non-Muslim, stating that she would prefer to live her life with an Iranian, Iraqi or Maghrebi Muslim (Françaises 192).

Polygamy is considered customary and acceptable in many Islamic countries if a man treats all his wives in a perfectly equal way. El Saadawi comments that the question of polygamy can be portrayed in two ways: one group of believers claims that polygamy is in fact impossible since it is human nature to show a preference. The other group insists on the fact that Mohammed himself had several wives; therefore it must be possible that there can be equality between several (81). From the first-generation immigrants on, there is a tendency not to have more than one wife because of the heavy financial burden men have in their new homeland. But that does not take away the fact that men use polygamy as a tool to overpower women. In Chapter Three, I will analyze this behavior through the writings of Saliha Scheinhardt.

\section{Divorce and Custody}

Juliette Minces explains that it is easier for a Muslim man to divorce than for a Muslim woman. A husband can repudiate his wife without justification, while a wife is required to prove why she should be allowed to separate from him. The husband has to speak the talaq formula "I divorce you" three times before a witness for renunciation to take effect, while a wife needs to request the dissolution of the marriage before a court of Islamic law. A man's responsibility towards his ex-wife stops as soon as the divorce is recognized, so most women have to return to their own families in order to survive financially. At this point they are subjected again to the same constraints that are exposed to the unmarried girls. It is a matter of their family's reputation to find them a new husband as soon as possible (65-68). Divorced women can keep their children only 
for a limited amount of time before the offspring are automatically placed under the custody of the husband. Visitation rights are very limited and in many instances wives will not have a divorce so as to avoid the unbearable trauma of being separated from their children. Family disputes for those women are much more taxing when they have settled in their new homeland since many immigrant women already struggle with feelings of alienation.

Although the Qur'an nowhere opposes contraception it is evident that most Muslim thinkers are opposed to abortion and the use of contraception. However, repeated pregnancies can be a health hazard for many women, so such issues are a constant concern for Islamic families who are now living in Western society where such practices are legal.

\section{Male Dominance and Honor}

In a patriarchal society, female members are dominated by their fathers, husbands and brothers. The "Family honor" system, rooted in traditional values, leads to confrontation within families living in Muslim countries. In her study on violence against women in the Arab world Nora Almosaed remarks that: "Generally, fathers and husbands have absolute authority over children and wives. However, their authority, as some studies report, is increasingly being questioned and challenged” (79). Many women who come from rural areas are more exploited than their urban sisters.

These difficulties are compounded for immigrant families by Western influences. Many second-generation women experience conflicts when attempting to assimilate while maintaining their socio-cultural ideologies. Violence and male dominance against women and children are increasingly seen as an area of considerable concern in the 
Western world. Western European countries such as France and Germany focus their moral and cultural values on the individual, who enjoys much more independence than individuals in the rural areas in Turkey, Algeria or Morocco. Parents and male relatives control women and girls to a large degree. The concept of premarital virginity remains very strong in Muslim communities. Fear and social pressures are very high and breaches of honor can have enormous consequences. ${ }^{4}$ Hamm comments that Turkish girls are more closely watched by their fathers and brothers in Germany than they would be in Turkey: "Freiräume türkischen Mädchen werden in der Fremde noch mehr beschnitten als in der Heimat. Dort können Töchter sich ungezwungen mit Freundinnen treffen, schließlich wacht das ganze Dorf; hier dagegen wird ihnen kaum frei verfügbare Zeit zugestanden, weil jeder Kontakt mit Gleichaltrigen die Moral zu verletzen droht” (150). [Turkish girls are kept on a tighter rein in their new surroundings than in their homeland. There, daughters can easily run around and visit with their friends because there is always someone in the village who keeps an eye on them. Here they do not get any freedom because each contact with the outside world could become an immoral encounter].

The young Algerian woman, Naïma, in Françaises comments:

Mais pour les parents, cela reste une infamie si leur fille n'est pas vierge le jour de son mariage. C'est la honte parce qu'ils ne l'ont pas assez surveillée. Maintenant, celles qui veulent faire croire qu'elles sont vierges

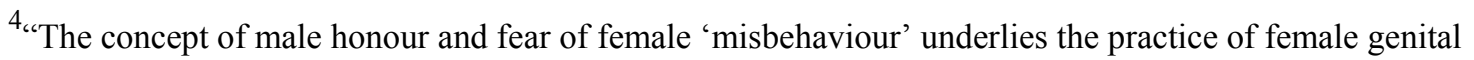
mutilation, which reflects a prevailing social consensus that virginity of girls and women must be preserved until marriage, and that their sexuality must be controlled. [...] Cultural practices continue to subordinate women and girls in the forms of child marriage and forced marriage conducted often to protect the family 'honour"' (Almosaed 74).
} 
vont voir les médecins: ils font facilement des certificats bidons. Il vaut souvent mieux mentir pour sauver l'honneur de sa famille" (190-91). [For parents it would be unthinkable if their daughter weren't a virgin on her wedding day. It would seem that they had not watched her closely enough. Nowadays the ones who want to look like they are still virgins simply go to the doctor and get a fake certificate. It is often better to lie to save the family honor].

Sarah Tiede Buchanan explains that those strict religious rules are used to control females: "the immigrant community uses women as a locus for waging a struggle to preserve a nationalist identity, because the "purity" of women's behavior, cultural practices and religious adherence is imagined as a locus of uncolonized and indomitable communal identity" (356). It is still common practice to keep women and girls in a subordinate position in order to protect the family "honor". Authors such as Samira Bellil who was born in Algeria but grew up outside Paris, were not passive victims. Rather she was actively engaged in changing the structure and she fought for her own independence. Those changes can sometimes have devastating consequences, as in Bellil's case. After being gang-raped at age 15 she was thrown out of her father's house only to live as an outcast in the outskirts of Paris where and she barely survived. Fifteen years later, after serious psychiatric help, she was able to tell her story in her memoir Dans L'Enfer des Tournantes [In Gang-Rape Hell]. Being able to get her point across that honor can destroy the lives of many Muslim women made her more powerful. For a couple of years she was able to help other young women who went through similar experiences. She was one of the organizers of "La Maison de Potes" where women in 
France can find shelter against their assailants. In September 2004 she died from stomach cancer at the age of 31. In the New York Times obituaries of Friday, September 10, 2004 she was named as "the godmother of the women's' right group Ni Putes Ni Soumises" [Neither Whores Nor Submissive]. Those circumstances where honor is the center of family disputes have had devastating consequences not only in France but also in Germany.

In the Berlin-Brandenburg community, a 23-year-old woman was murdered in the winter of 2005 by her brothers in an 'honor killing'. The article “"Ehrenmord' in Berlin" states:

Hatun Sürücủ wurde Anfang Februar in Berlin ermordet. Alles deutet darauf hin, dass es sich um einen sogenannten "Ehrenmord" handelte. Die 23-Jährige soll die Ehre der Familie in den Schmutz gezogen haben - weil sie sich aus einer erzwungenen Ehe befreite, weil sie ihr eigenes Leben führte, vielen Widerständen zum Trotz. Mit ihrer Familie lag sie seit langem im Streit, von einem Bruder war sie schon bedroht worden (1).

[Hatun Sürücủ was murdered in Berlin in the beginning of February. Everything points to a so-called "honor killing". The 23-year-old allegedly dragged the honor of the family in the dirt because she liberated herself from a forced marriage, while she led her own life, in spite of many mishaps. She was in conflict with her family and she was already threatened by one of her brothers.]

The article further explains that so far there are no statistics regarding 'honor killing' in Germany but that at least five similar murders had taken place in Berlin two months before this one occurred in February 2005. This has prompted political and private 
groups to address this difficult situation and to call for a total elimination of similar shocking crimes.

\section{Head scarf, Veil or "Hijab"}

Islamic women are more visible when they dress in long traditional garments and when they wear a headscarf. Being dressed this way does not only show their religious background but it gives away their Middle-Eastern heritage. Garbi Schmidt comments: "when a Muslim woman chooses to don the hijab she knows that her garment sends a strong signal. She visibly interprets faith and religious identity in her personal way, and transmits the signal to Muslims and non-Muslims alike" (33).

In 2004 a law was passed in France that banned the headscarf in state schools and state-run educational institutions. Anthony Giddens observes that the battle of the hijab is not only a French problem but one that constitutes a heated topic in many other countries. In Bavaria and Baden-Würtenberg, Germany, there have been similar laws concerning the headscarf, and in Turkey the hijab disappeared when Kemal Atatürk - in the 1930s and 1940s - attempted to westernize his country (9). France is the only totally secular state in Europe, and because of the complete separation between state and religion, did not want to allow religious symbols in public schools. The "affaire du voile" [the headscarf issue] started in 1989 in a town Creil, where several schoolgirls were suspended because they were wearing a 'hijab'. Soheib Bencheikh, the Grand Mufti of Marseille, France is in favor of the headscarf ban because he says that now Islamic communities will enjoy the same rights as Catholics. When he was asked if Muslims feel that they have assimilated to their new country he answered: "When we read through history, we will find that Islam always interacts with many cultures. In 
addition, secularism implemented in France is a form of pure neutrality. We can interact with the French culture that has a background of Catholicism, while holding on to our spirituality and Islamic values" (Novariantoni 4).

The headscarf is not only a religious symbol but also a political and a social mark. The religious rationale for using a veil is rooted in the belief that a woman should not draw attention to herself and that she should dress simply and be modest. ${ }^{5}$ Socially, the veil can function as a symbol of submission. This has become more and more of a problematic issue since more women participate in public life through their work and education. Sonya Dayan-Herzbrun argues on the one hand that opponents of the headscarf are trying to help young women against the male dominance of fathers and brothers who do not let them choose for themselves whether they will wear it or not. On the other hand, the headscarf identifies them with a religious group and makes them feel part of a community, a notion which is very popular with young immigrants. She explains further that the West often does not realize that the wearing of the hijab is usually a sign of higher class status. Poor women, such as peasants, do not wear a headscarf. The veil then is a mark of a woman's exclusion but it is also a means for her to socialize (73-75). The Western interpretation considers the headscarf a mark of submission and domination, but in many instances it is the Muslim women themselves

\footnotetext{
5"Say to the believing men that they should lower their gaze and guard their modesty: that will make for greater purity for them: And Allah is well acquainted with all that they do. And say to the believing women that they should lower their gaze and guard their modesty; that they should not display their beauty and ornaments except what (ordinarily) appear thereof; that they should draw their veils over their bosoms and not display their beauty except to their husbands, their fathers, their husband's fathers, their sons, their husband's sons, their brothers or their brother's sons [...] And O ye Believers! turn ye all together towards Allah, in repentance that ye may be succesful." (Qur'an 24:30-31 Sura)
} 
who want to wear it as a sign of social prominence or simply as an indication of religious adherence. Naïma suggests yet another factor in a girl's decision to wear a hijab:

Elle est en troisième lorsque éclate l'affaire du "voile islamique". Le proviseur interdit les cours à trois élèves d'origine maghrébine qui refusent d'enlever leur foulard. "Par rapport à moi, elles n'étaient par sérieuses. Elles étaient plus libres, sortaient avec leurs copines et travaillaient plutôt mal en classe. En fait, le foulard ne les empêchait pas de profiter de la vie. Je pense même qu'elles s'en servaient comme d'un paravent pour paraître sérieuses aux yeux de leurs parents et faire ce qu'elles voulaient derrière (Françaises 166).

[She was in the $9^{\text {th }}$ grade when the controversy of the "Islamic headscarf" erupted. The teacher did not allow three Maghreb students in her class because they refused to take it off. "For me, the students were not very serious. They did what they wanted with their friends and they did not study very hard. Certainly the headscarf did not stop them from having a good time in life. It is more used as a shield because with a headscarf they give the impression to their parents that they are serious. When they are alone however, they do whatever they want to do].

For Naïma, then, members of the younger generation know how to circumvent the intent of the veil and have learned to use it for their own benefit. In an oppressive situation, the veil can become an asset, when it is used as a public sign of religiously sanctioned behavior. In this situation, not only does the headscarf provide young women with a sense of belonging, but at the same time it gives them a sense of liberation. 


\section{B. Language Barriers and Education.}

Because of the high cost of living in Germany and France, immigrant women need to work to survive in their new homeland. As Fennell writes, they do so for a much lower wage than their male counterparts: "Within the foreign population, however, a woman's salary is much lower than a man's. [...] The structural reasons for this are the lower educational and training level of foreign women and their under representation in salary negotiations" (38). Female employment is mostly found in domestic cleaning services, which are not only poorly paid but also entail physical exertion. This commonly leads to health problems, insecurity and low self-esteem. Muslim girls are in many instances prevented from pursuing vocational training. Like their mothers, they have to take unskilled and semi-skilled jobs (39-44).

The younger generation has to adapt to a western education system which usually includes learning the language of the host country. Poor language skills, cramped living quarters, and authoritarian parents often impede girls from being integrated into the school system, since at home they must follow the rules and values of their Islamic families. The authors of Françaises note that when Naïma comes back home from primary and high school she has to help her mother before she does her homework. She makes the beds, does the dishes, cleans the carpets, kneads the bread... After dinner, it is the same scenario: she cleans the table, does the dishes and sweeps the floors. It is only when all those chores are done that she can start her homework (150). As Naïma's story illustrates, girls are responsible for housework and have to take care of their siblings before they can start with their own schoolwork. Moreover, they have to attend religious 
schools, where classes are conducted in Arabic. The result is that they are constantly on the defensive, both at home and at school.

The combination of these factors creates difficulties in both situations. Carol Pfaff explains that for Turkish immigrants in Germany, the language situation is particularly interesting, since German and Turkish belong to two completely different language families. In the first generation when Turkish speakers acquire German, pidginization occurs because the new immigrants have to communicate in a simplified language that is also called Gastarbeiterdeutsch. The second and third generations have expanded this language to a Creole language, a pidgin that has been acquired by native speakers and that gradually moves closer and closer to standard German (156-58). Mastering the German language can result in social isolation and problems can arise. More and more children become more proficient in the language of their new country and lose more and more of their skills in the language of their parents. Many children have problems communicating with their parents who only speak their native language. The situation is further complicated by the role of the Turkish language in the family circle and among the younger generation. As Tietze points out, Turkish is still significant: “L’importance de la langue turque qui est toujours parlée dans les familles et parmi les jeunes adultes de la deuxième génération, et la diffusion considérable de média turcs (journaux, chaînes de télévision etc.) dans le milieu des immigrés de cette origine constituent des piliers solides pour la formation du lien diasporique” (253). [The importance of the Turkish language, still spoken at home and amongst adults of the second generation, and the widespread Turkish media (newspapers, television stations 
etc.) in those homes, make a solid foundation for the formation of diaspora connections]

In addition to these difficult linguistic, academic and cultural conditions, the second generation can experience heavy pressure from their parents who want them to realize their own unfulfilled dreams. Constant conflicting demands from both educators and parents lead to psychological problems such as depression, stomach ailments, hysteria and sometimes suicidal tendencies (Hamm 95). This dilemma is usually called in German Nirgendwohin, a feeling of not belonging anywhere.

The German government is trying to find a better solution to integrate religious classes by featuring a new subject in the curriculum, namely 'Islamic education'. Those classes began in 1999 in the state of North-Rhine-Westphalia where about 800,000 Muslims reside. The fact that those classes are taught in German shows that the government is contributing toward integration in the everyday life of the school-age population ("Learning about Mohammed" 1).

The French school system by contrast does not allow any religious instruction. Muslim communities and parents have to find another way to provide religious education. The teaching of the Qur'an has been established in mosques and communities outside the state school system. The problem of language barriers for the second generation of Moroccans and Algerians presents itself in a very different manner. Most of the parents speak French or are at least familiar with the language, since it was the official language of the home country in the beginning of the $20^{\text {th }}$ century during the French colonization of North-Africa. 


\section{Xenophobia and Racism in Western Europe}

In most Western European countries xenophobia and racism are a reality for foreign workers. These problems have increased since recent terrorist attacks. Heike Henderson comments: "Europe has had to come to terms with its Muslim minorities. Racial hostility toward Islamic people has manifested itself in complex ways as violence and hostility to Turks in Germany and North Africans in France...” (228).

As already discussed above, females wearing the hijab and long garments give expression to their Islamic faith, visibility that can be seen as a threat. For the last two decades the number of residents of Muslim descent has increased in great numbers in Western Europe, which has been transformed into a more multi-cultural society. Gisela Brinker-Gabler and Sidonie Smith look back into history and compare the increase of violence in France to hostility and xenophobia displayed in Germany in the beginning of the $20^{\text {th }}$ century. Both the prosperity of those Western European countries and the French colonization have contributed to the growth of the immigrant population. In 1997 there were 3 million immigrants in France, among a total population of 55 million. Maghrebi immigrants are the largest immigrant group of which the majority is of Muslim faith. ${ }^{6}$ During the same period Germany had 7 million immigrants among a total population of 79 million. Of the 7 million, about 4 million are of Turkish origin and an estimated 2.9 million are Muslims (6-7).

Winifred Woodhull explains that since a great number of formerly colonized inhabitants settled in France “...many French people became anxious - not so much

\footnotetext{
${ }^{6}$ This can be misleading because in France immigrant European groups such as Italians and Portuguese are larger than the Maghrebi group, but they are not portrayed as immigrants since their culture is not so different from that of the native French population. (La France contemporaine 202)
} 
because they were confronted by cultural differences, but because it was becoming difficult to tell the difference between themselves and the 'others' who lived in proximity to them in their urban world" (43).

For the Maghrebi society it is not only culturally and racially different, but also the Islamic religion plays a large role in how the autochtonous population perceives them.

During French elections in 1983 there was a huge demonstration in Marseille because of the victory of the ultra-right party led by the nationalist Jean-Marie Le Pen. This manifestation was called the 'Marche des Beurs' and was organized by the younger immigrant population. 'SOS Racisme', an anti-racist organization was founded by Harlem Désir, who was born of a Senegalese father and a French mother. "Touche pas à mon pote" (see S. Belllill p. 12), was the slogan of 'SOS Racisme' which became a significant movement among this younger generation, which has become more interested in the political integration of immigrant groups (La France contemporaine 208-9).

Fennell articulates prejudices of the native inhabitants' of Germany as follow: "The more directly threatened people feel by foreigners, in terms of employment, social prospects, competition for housing, social benefits etc., the more likely they are to experience direct feelings of prejudice and hostility against the foreign population" (48). Turks have especially been singled out for racist attacks, mainly because of their different language, religion and appearance. In 1992 there were more than two thousand attacks on foreigners ranging from arson to murder. On September 20, 1991 a group of rightwing extremists attacked immigrants in Hoyerswerda followed in August 1992 by more attacks in Rostock-Lichtenhagen. In addition there was a gruesome murder of a Turkish worker and his two children in Mölln and other attacks on Turkish immigrants in 
Solingen. Those attacks occurred primarily in the former East, where unemployment was higher due the reunification of Germany. For the most part the German police did not intervene in any of these crimes which took place in small towns and villages where the effects of racism and xenophobia are often expressed more openly than in the larger cities. Although the slogan Ausländer raus [foreigners out] is rejected by $89 \%$ of the German population, there is "no doubt that dark-skinned foreigners and Muslims are the hardest hit by the xenophobia" (Fennell 49). In 1992 there was a huge manifestation against racism in Berlin where more than 300,000 held peace vigils. Civic campaigns were set up both in Germany and France in order to ease racial tensions and to facilitate integration.

\section{Dual Citizenship and Immigration Policies in France and Germany.}

Strict immigration policies are in effect in both Germany ${ }^{7}$ and France ${ }^{8}$, and specific laws have been passed that pertain to dual citizenship. Historically those laws

\footnotetext{
${ }^{7}$ A law was passed in 1913 which is based on ius sanguinis: "Deutscher ist nicht der, der in Deutschland geboren wird - nein, Deutscher ist nur der, der von Deutschen abstammt" (Fennell 33). [A German citizen is not citizen when he is born in Germany - no a German citizen is only a German if he/she is of German ancestry].

${ }^{8}$ For French citizens "le droit à la nationalité française repose sur deux notions fondamentales: le droit du sang (naître d'un parent français) et le droit du sol (être né sur le territoire français). La notion de nationalité a évolué en fonction des intérêts politiques de l' État. En 1851, par exemple, à une époque où l'État voulait faciliter l'acquisition de la nationalité française par les travailleurs immigrés (Belges, Suisses, Alllemands) le double droit de sol a été instauré: toute peronne née en France d'un parent lui-même né en France est française à la naissance. Le double droit du sol aura des implications au siècle suivant et s'appliquera aux enfants de parents algériens puisque l'Algérie était un département français jusqu'en 1962 (La France contemporaine 211). [The right for French nationality is based on two fundamental notions: the blood right (born of French parents) and the birthright (being born in a French territory). This notion evolved depending on the political interest for the State. In 1851, for example, at a time when the State wanted to facilitate the acquisition of French citizenship by foreign workers (Belgians, Swiss, Germans) the double birthright was established. The double right will have implications during the next century because it will have to be applied to the children of Algerian parents, since Algeria was a French department until 1962].
} 
have varied greatly especially those concerning immigrants and host countries. There are different approaches for the Turkish-German group and the generation born from Algerian or Moroccan families who reside in France.

A compromise needs to be found for the status regarding permanent residency and ultimately citizenship for the Turkish-German immigrants. Second-and-third generation Turkish workers have lived in Germany for over 35 years and the majority of their children are born there. In the 1990's laws made it possible for foreign workers to apply for citizenship, if they had been permanent residents for at least 15 years. In this case the requests and the applications had to be made before 1995. Children between 16 and 23 could apply for citizenship after 8 years of residency (Fennell 32). Whoever is born in Germany after January 1, 2002 can become a German citizen if the parents continue to reside in Germany. When they reach adulthood they must choose which citizenship they desire. When they apply for citizenship in another country they lose their German passport. This complicates matters because since the reform of the citizenship rules many naturalized Turkish-Germans had already applied for Turkish passports. The problem was that the Turkish authorities took many years in order to process those applications. Potentially, according to a recent poll, up to 50,000 Turkish-Germans could lose their German passport and be expelled from Germany. This current political dilemma still needs to be resolved (Graupner 1).

As explained above, French nationality has been given to Algerian citizens who were born before 1962. According to the Code Civil a person born of French parents or born in France automatically becomes French. As explained above, French nationality has been given to Algerian citizens who were born before 1962. Furthermore their 
children automatically became French citizens at that time. In 1993 the "loi Pasqua" introduced a rule against polygamy. When Maghrebi citizens wanted to enter France they had to apply with only one wife not with several. In 1996 the "Loi Chevènement" regularized laws in order to help immigrants who entered France without any legal papers.

The immigration of Turks and North Africans is not a phenomenon unique to France and Germany but has also affected neighboring countries. In fact Thérèse De Raedt points out that Belgium is "on the vanguard of European nations" in more than one aspect of immigration. She states that "Belgium unlike most Europeans countries, encouraged the immigrant to migrate with his family" and "that it became just as important for the immigrant to reproduce as to produce." On 19 July 1974 Islam became an official religion in Belgium, the first country to accord it a public status (15).

Even though many second-and-third generation immigrants have a new European nationality it will become evident that most of those families will stay in their own neighborhoods and that solidarity is becoming noticeable between Muslims that come from different regions of the world. In those communities they share a feeling of alienation and they build a solidarity which gives them a feeling of belonging. 


\section{CHAPTER TWO:}

\section{IDENTITY PREDICAMENTS FOR BEURETTES IN FRANCE AND FEMALE GASTARBEITER IN GERMANY}

In both France and Germany, Muslim immigrant groups who come from different backgrounds tend to settle in their own newly formed communities. In France, immigrants come with a strong Islamic religious background whereas most Turkish families in Germany bring with them forceful patriarchal cultural traditions but may not necessarily be of the Muslim faith. Many of them, who are in search of a better life in the West, come from rural areas where this patriarchal structure is the foundation of family life. Foreign settlers share socio-cultural values that give them a sense of belonging. Muslim male immigrants moved to Western Europe mostly for economic reasons and brought their own families over only once they had established themselves. It is from the second or third generation on that immigrants try to modify their status in their new homeland, since most of them were born there. They struggle with an unsettling situation of two worlds, two languages, two traditions and two cultures. This hybrid life complicates their search for identity.

Brinkler-Gabler and Smith show that millions of women who have immigrated to Western Europe have multiple challenges to overcome their "otherness":

These women are variously subjects within discourses of nationalism, rights, and citizenship, discourses through which their otherness within comes to signify and to materialize in the allocation of rights, privileges, and resources in their new nation. For instance, their sexual, racial, ethnic, 
and class positioning conjoin in the assignment of a particular status. They may be migrant or immigrant, foreign national, ethnic or racial minority, guest worker, or resident alien. These assignments of identities have material and cultural effects (15).

In this chapter, through a study of the novel Beur's Story set in France and the movie Gegen die Wand set in Germany it will become apparent that the female protagonists in both stories battle constantly to retain their sanity, threatened by the cultures of their heritage. They long for acceptance in their new homeland and from their own families but are rejected by both. An understanding of the labels Beur and Gastarbeiter is essential to understand these women's predicaments.

\section{A. Reflections on and Reactions to the Term Beur}

Historically France has seen a larger number of immigrants since the start of the $20^{\text {th }}$ century because of its former colonies. Anissa Talahite describes the complexity of the relationship between migrants and a host country that once was the colonizer:

Post-colonial theory has highlighted the multiple and complex ways in which identities operate within the context of the relationship between the colonised and the coloniser, between the ex-colonised and the ex-coloniser as well as the between the "migrant" and the former colonial power having become the "host" country (56).

The steady increase of immigrants has changed the face of French society. Maghrebi immigrants who came after the 1970s started to settle in France permanently. This group of migrant workers brought their extended families to their new adopted 
country. As a result, the demographics changed visibly with the emergence of a new generation whose members felt that they belonged neither as an 'immigrant' nor as a 'guestworker':

Avec les regroupements familiaux, leur sédentarisation dans le pays d'accueil est marquée non seulement par des investissements de ce type mais aussi par l'apparition d'une nouvelle génération de jeunes Maghrébins nés en France, qui ne sont ni "travailleurs" ni “immigrés" et dont les pratiques culturelles deviennent rapidement plus visibles que celles de leurs parents (Hargreaves 28-29).

[With family regrouping, settlement in the country that welcomed them is marked not only by investments of this type, but also by the emergence of a new generation of young Maghrebi who are born in France. They do not perceive themselves as "guestworkers" or "immigrants" and their cultural practices become much more rapidly visible than those of their parents'].

Contrary to the immigrants from Italy and Portugal, members of the second generation of North Africans feel threatened because they do not receive the same treatment from the indigenous French citizens as noted in Chapter I, p. 18. Although they speak French and absorb French culture, they are not accepted and endure much more racial discrimination. They struggle to find better jobs, only to be relegated to menial ones. Moreover they live in the banlieues in ghetto settings, where they are more prone to get into fights with the police. De Raedt observes how Belgium and France differ in the geographic movement of immigrant neighborhoods. Belgian immigrants started to establish themselves in the downtown areas because the autochthonous population had 
relocated to the suburbs. This is in contrast to France's cités $H L M^{9}$ where problems of social marginalization occur (20).

The term "Beur," ${ }^{10}$ created from le verlan, was given to children of North African workers who were either born in France or who had come to France at an early age. Sylvie Durmelat states that the reversing of the word arabe to beur shows that the latter is a distortion of the original word. By this reversal she explains that the immigration process for Maghrebi immigrants has been inherent to their desire to return to their homeland, especially in the case of the original settlers. Even though the desire to return has been very powerful, younger immigrants realize that this will be impossible since the majority of them are by now French citizens (32). They have been educated in the French school system, an important factor for assimilation. Being exposed to the French language on a daily basis, civilization and history in a classroom help the integration of the immigrants.

Gafaïti wonders if Beur can be used in the same way any longer, since it seems to have lost this positive meaning (10). He further observes that young Maghrebi people do not approve anymore of this label: “Aujourd'hui, les jeunes Français d'origine maghrébine soit refusent toute étiquetage et se désignent comme Français simplement, soit se dénomment eux-même par le terme 'Arabe' ou 'Kabyle' selon leur origine ethnique arabe ou berbère" (11). [Nowadays young French of Maghrebin origin refuse this label and refer to themselves simply as French or, if they use a denomination, they

\footnotetext{
${ }^{9} \mathrm{HLM}=$ habitations à loyer modéré / low-rent, state-owned housing, or project housing.

${ }^{10}$ “The word beur is an example of le verlan, a type of language developed in les banlieues, où tout est dit à l'envers, [The suburbs where everything is said in reverse]. The word verlan itself is the word l'envers backward. Beur is Arabe backwards" (Levieux 26).
} 
use the term 'Arabe' or 'Kabyle' depending if they are of Arab or Berber ethnic origin]. This word changed from one stamped and used by the immigrants themselves only to become a derogatory and racist epithet thrown at them by their fellow French citizens.

Racism and animosity towards les Beurs are prevalent because of cultural differences, and they produce tension and aggression. Woodhull comments that les Beurs themselves feel that integration will be extremely difficult:

By and large, Beurs see themselves, and are seen by other French people, as being caught between two separate and incompatible cultures, with little chance of being fully integrated into either one. As a result, they are subject not only to an unsettling and sometimes debilitating crisis of personal identity, but to rejection by two national groups, exclusions from two homelands (32).

Talahite expresses a more positive interpretation of the term Beur by observing: “The term 'Beur' also brought an end to the negative meaning that had become synonymous with the word 'Arabe', almost systematically a term of racist abuse" (59). Beur culture has emerged in France through its own Beur literature, Beur music and through Radio Beur, established in 1981. The aim of this radio station was to introduce the culture of the second generation of North-African decent through the media. During the government of François Mitterand politicians tried to find a more multicultural approach and encouraged ethnic minorities to express themselves. Bridget Knapper states that Beur FM, the successor to Radio Beur began broadcasting in 1992. Beur FM was established as a professional commercial station with no state subsidies. Knapper explains that with the aid of satellite the station can broadcast to the Maghreb and all over 
the world. It acts as a cultural reference for the Maghrebi diaspora and it is "...an example of cultural products breaking territorial boundaries" (4). On one of the main programs, “L'Invité de Beur FM", guests come to discuss certain issues and listeners can ask direct questions. One of the reviewers, Ahmed El Keiy, is especially interested in discussions concerning "the lack of representation of people of Magrhebin origin as electorial candidates" and "the lives of women of the south Mediterranean". Such programs enable listeners to express themselves and give them a feeling of belonging where as before they felt isolated. Another significant part of Beur FM is its music, which is influenced by North African rhythms and melodies. Many songs deal with difficulties that the Beurs endure and, in addition, it helps them explore their own identity through a medium that is becoming increasingly popular with all French people (4-8).

Beur literature is another crucial venue that shows how hybrid generations cope with their "double" life in France. In the third chapter I will concentrate on works by a female author, Leïla Sebbar, whose work has been inspired by this particular generation. Through her writings, which are predominantly autobiographical, she tries to find a cultural bond between two conflicting worlds.

\section{B. Observations on the Label Gastarbeiter}

The German immigrant worker is labeled as a Gastarbeiter. The name did not start out derogatory; it became that way because of the prejudices in German society. The term means literally "Guest worker", which is a description of a migrant worker. As the name Beur in France, Gastarbeiter has the same derogatory implication and is considered politically incorrect. The preferred term is now either ausländische/türkische 
Mitbürger [Foreign/Turkish co-citizens] or Deutsche-Türken [German-Turks]. As was the case in France with the Maghrebi people, Turkish immigrants did not return to their homeland but settled in their host country. From the second generation on, one sees an improvement in opportunities for this group although they remain outsiders with respect to the German mainstream. Particularly important to consider are the Turkish immigrants' concerns and apprehensions regarding integration in their new country. Lale Yalçin-Heckmann stresses that the perception of the second generation of the TurkishGerman population greatly relies on how the media make German citizens aware of how the newcomers should be assimilated in their new environment. As discussed in Chapter I, many Turkish residents who have been living in Germany for over 35 years still have not received citizenship. Although as a result they are excluded from voting in local or national elections, Yalçin-Heckmann observes that gradually the second and third generations are receiving more attention because of attention paid to creating a multicultural society in Germany:

With the social differentiation within the Turkish migrant community, and with increasing debates about the nature of multiculturalism in Germany, there seem to be new trends in public discourse about introducing new identities for migrants.. Second-generation Turks in Germany especially are subject to these discussions of identity (313).

She explains that the hybrid identities are not seen in the first generation of Turkish immigrants but that "[...] the hyphenated identity attributed to youngergeneration migrants therefore empowers them as belonging to two cultures, encompassing both, not torn between them" (315). Similar to what is taking place in 
France, German-Turks are increasingly represented in the media through popular culture, music, literature, and telecommunication. Adelson defines the appropriate term for literature that this group represents by calling it Gastarbeiterliteratur [guest workers' literature], Ausländerliteratur [foreigners' literature] or Migrantenliteratur [migrants’ literature] (217). Both in France and Germany female immigrant writers do not get the respect they deserve. It will become clear in the following chapter that through immigrant literature, women authors can have a positive influence on their sisters and daughters. They have endured similar experiences and they report on females that have been in similar predicaments. Smith and Brinker-Gabler insist that some immigrant women use literature as a means of changing themselves and finding their new identity in a multicultural setting:

In the practices of everyday life, immigrant women confront and grapple with their status as an "other" within the imagined community as well as their multicultural identifications. They struggle with the very real material circumstances of their differential treatment and experiences as migrant and immigrant women as well as the differential impacts of racial, ethnic, and class differences. In the process of doing so, some immigrant women take up writing as a means of constituting and changing themselves as subjects (16).

Even though the second generation of Turkish immigrants has bred more authors, Horst Hamm shows that they are still living in an ambiguous world in which they experience cultural and sociological conflicts in both worlds: 
Es sind vor allem die in deutscher Sprache schreibenden Autoren der ersten Generation, die neue Bilder finden und die deutsche Sprache verändern, indem sie sprachliche und menschliche Erfahrungen aus zwei Welten in ihren Texten miteinander vereinen. Die Zweite Generation schreibt zwar ungleich mehr, ihr gelingt dies jedoch nicht (44). [It is especially the authors of the first generation who write in the German language. They find new images and through this they change the German language. In their texts they combine language and their personal experiences from both worlds. Even though the second generation composes far more, they still do not succeed in it].

Hamm observes that the second generation suffers from living in two cultures and two worlds since what is socially correct in one is often forbidden in the other: "Wer bikulturell sozialisiert wird und zweisprachig aufwächst, entwickelt eine Identität, die ihn nirgendwo 'zu Hause' sein läßt, und bleibt ein Wanderer, ein Fremder ohne kulturelle Heimat.” (91). [Someone who is socialized in two cultures and grows up in a bilingual situation, develops an identity in which one does not feel 'at home' anywhere. This person remains a wanderer, a foreigner without a cultural homeland]. He alleges that American studies have found a correlation between bilingualism, lower IQ and personality disorders. Children of Gastarbeiter can suffer many psychological problems that vary from disorientation to neurological deficiencies (91). Faruk Şen illustrates that a term such as Deutsche türkischer Herkunft [Germans of Turkish decent] is becoming the norm. Increasingly more migrants are applying for German citizenship. Complicated 
immigration policies are circumvented by Deutsche türkisher Herkunft who bring a bride from Turkey and can ensure that the young woman will receive German citizenship as well. Because of traditional Turkish society and a lack of education, young Turkish women often arrive in Germany only to find themselves in very difficult situations. They become economically dependent on their new and frequently pre-destined husbands. They often have to live under precarious conditions because they are trapped in a subordinate role. They have no other place to go, and divorce is usually not an option because in their tradition their families back home would not take them back since they belong to the husband's family when they were married. Furthermore they cannot go into the workforce because they do not speak enough German to be able to obtain a decent job. Topçu explains that through the mass media more women are becoming aware of their situation (6). Şen points out that reunification of the families brings positive outcomes because the children receive a complete German education. It further closes the gap between the younger and older generation (28-29). He shows that Turks have created for themselves a place where they feel comfortable in their new homeland:

The Turkish immigrants are now able to find everything in Germany which they used to miss: friends, enemies, mosques, shops, food varieties, Turkish television channels, Turkish newspapers, Turkish organizations, cultural services and so on.[...] Other organizations brought from Turkey authors, artists, musicians, films and theater groups (30).

Through telecommunication and the Internet Turks can connect with their extended families in Turkey while living a new life in Germany. The Internet is a communication 
medium that allows women and youth to find important information that before was not discussed or was a forbidden subject in the traditional media. Since it is a means of communication that is oriented to the individual, it can provide crucial insight about women issues that is still taboo in a traditional setting. It can give valuable links to specific women organizations who can help women in need. It is becoming more and more popular with these groups especially with the younger generation. This communication instrument is geared towards individual use and can be accessed by women outside of family control. E-mail can help women who are socially isolated and can weaken the control that males have over females as well (Shteiwi 2).

Topçu writes that $20 \%$ of the original guest workers were females. From the 1970s on, German companies increasingly employed more women from the rural areas of Turkey. These women became more liberated from the patriarchal system in which they had been living and gained self-confidence and emancipation (4-5). Daughters of Turkish immigrants want to study at German universities and many do not have a problem finding a happy medium between on one hand, Western life, and on the other hand, the inevitability of marriage and obedience to the rules of Islamic religion (8).

With the Turkey's desire of coming of part of the European Union, many laws and changes were affected by women in order to improve the difficult position that Turkish women face when they arrive in the Western world. Education has become a necessity for improving their situation. All over Germany centers have been opened so that women can find refuge and an opportunity to extricate themselves from the current patriarchal system. On January 1, 2005, new immigrant laws came into effect stating that every immigrant entering Germany from a non EU country is obliged to take a course of 
30 hours in German culture, law, and history. Every immigrant needs to enroll in a language course that consists of 600 hours. A test is given at the end of the course and in case of failure the person will have to show his/her link with Germany every five years (Hummel 28). Knowledge of the German language will enable women to gain easier access into the workforce and ultimately it will contribute to closer contact with the German population.

C. Similar Predicaments that Second Generation Females Encounter in Beur's story and

\section{Gegen die Wand.}

It is apparent from exploring the Maghrebi and Turkish immigrant groups that both the second generation and their children are coping with feelings of alienation because of their hybrid identity. Muslim women especially are caught between sometimes irreconcilable values and this can lead to depression and dire straits. Both female characters from Ferrudja Kessar's novel Beur's Story and the female protagonist Sibel in the movie Gegen die Wand ${ }^{11}$ try to find a way to free of the constraints of their traditional Muslim families. In order to facilitate a good understanding of the novel and the movie I will give a short summary of both plots.

In Beur's Story both main characters Malika and her best friend Farida are constantly struggling with their own identity because they both want to escape from their patriarchal family environment. The novel is situated in the city of Le Havre, France where the 18year-old Malika is the eldest daughter of an immigrant Maghrebi family. Through her

\footnotetext{
${ }^{11}$ It should be noted that Gegen die Wand presents a male's point of view of women's issues.
} 
studies she hopes to escape the constant pressure of her family and go back to Algeria to pursue her education. Her best friend Farida, who is more rebellious, tries to find her own freedom by staying out with some male friends after school, but she is totally sequestered by her family when they discover her behavior. Paternal control suffocates Farida, who commits suicide by jumping out of a window. Malika cannot accept her friend's death, falls into complete silence and loses complete control. Farida showed her how to become free of a male dominated society and with her loss she does not have the strength to fight back anymore.

In Gegen die Wand, Sibel Kekilli, a 20 year old young woman of Turkish descent, is being treated for suicidal tendencies. Coincidentally, at the same doctor's office, she meets Cahit, a 40- year-old Turkish immigrant recovering from alcoholism and depression. They decide to marry for different reasons. For Cahit, marriage is a convenient arrangement and he appears to be bored with life. Sibel yearns for freedom, as marriage takes her away from the confinement she experiences in her traditional Muslim family. Whereas Cahit falls in love almost immediately, Sibel is not so quick, and she has random relationships with several men. Devoured by jealousy, Cahit kills one of Sibel's lovers and is put in jail. Since the family honor is ruined by these events, Sibel runs away to Istanbul. Life is not easier for her there. She struggles to find a job and again she is attacked and brutally beaten by several men. When she is at her lowest point she meets a taxi driver who picks her up after she has been assaulted. She settles down with him and starts a family. When Cahit is free he attempts to find her in Istanbul, hoping she will go back to Germany with him. Torn between him and her new family she eventually decides to stay in Turkey, where she has found stability. Honor, parental 
control, tradition and violence are some of the many motives that are intertwined in both stories. Malika's mother is very demanding towards her daughters but especially towards Malika who, as the eldest daughter, needs to show respect to her parents and her male relatives. Her father who is living on disability is mostly congenial with his daughters as long as his honor is not compromised:

Il portait le même amour à ses fils et à ses filles, ce qui n'empêchait pas son jugement d'être sévère et ses coups brûlants lorsqu'on touchait à son honneur. Les deux sœurs trouvaient d'ailleurs que son sens de l'honneur dépassait largement les bords. Car bien entendu, c'était sur leurs épaules qu'il était déversé en premier lieu (Beur's Story 43).

[He had equal love for his sons and his daughters, which did not prevent his judgment to be very strict and his blows to be very severe when his honor was in question. The two sisters knew very well that his sense of honor went much further for them. Because, of course, this honor weighed in the first place on their shoulders.]

Tradition and male control weigh heavily in Malika's life. Paradoxically, her only way out of family tyranny is to excel in school so that she can pursue her education in Algeria. As is typical in an Algerian upbringing, she is responsible for all the housework and for caring for younger siblings. The only time she experiences some freedom is when she goes to school. Otherwise she, as a daughter, is confined to her house:

Depuis leur jeune âge, ils avaient été séparés par un mur invisible que les parents plus que les traditions ou la religion avaient dressé entre eux. 
Alors qu'elles étaient enfermées et soumises, leurs frères jouissaient d'une totale indépendance. Ils avaient tous les droits, même celui de vie ou de mort sur la gent féminine de la famille (Beur's Story 56).

[From the youngest age, they had been separated by an invisible wall that their parents, even more than tradition and religion, had erected. They had been locked up and subjugated while their brothers enjoyed total independence. They enjoyed a wide range of rights, even the right to kill their female relatives.]

Not only is Malika subordinated to her father, obviously, but she also has to submit to the will of her eldest brother Mohamed. He is the main breadwinner of the household, and he physically abuses Malika and her sister without ever having to explain himself:

Mohamed était le véritable chef de la famille. A vingt-huit ans, il semblait taillé tout entier dans le roc, grand et large d'épaules, il en imposait, et on ne se discutait jamais ses initiatives. S'il décidait que le noir était blanc, il serait blanc. [...] Toute la famille dépendait de son salaire et de son jugement. Ce qui expliquait en partie son autorité. [...] Il frappa de son lourd poing la table pour accentuer son rôle menaçant (Beur's Story 37). [Mohamed was the real head of the family. Being 28 years old he seemed to be cut from one stone. He had large and big shoulders, was imposing and one never discussed his initiatives. If he decided that black was white, then it became indeed so. [....] The whole family depended on his salary and his judgement. This explained in part his authority. [...] He banged his fists hard on the table to accentuate his menacing role]. 
Woodhull speaks of Malika's story as that of a "girl's painful experience of leading a double life" and explains that both Malika and her best friend Farida "fail to establish an identity of their own 'somewhere else'; Farida kills herself, while Malika succumbs to madness. Their failure to establish a full, stable identity is presented as a tragic feature of Beur existence; it is not seen as a general condition of modern life" (38).

Sibel is in a similar situation although the setting is different. In order to escape the hardships of patriarchy, she opts to marry a very unstable man who does not even acknowledge her existence at the beginning of the story. Her family does not help her once she leaves, so she has to endure male violence and rape, which lead to psychological instability. Only when she flees to Istanbul will she be able to leave this world behind and find some kind of serenity by raising a family of her own.

In Beur's Story and Gegen die Wand it is apparent that the complexity of problems for females of second-and-third generation immigrants is very similar in France and in Germany. The main female characters in the novel and in the film imagine that going back to their roots will be bring them happiness and freedom. This is atypical for most second and third generations who on the average will stay in their new homeland. This tale of honor and male dominance is repeated across Western European countries where immigrant women have settled. In France when telling her story, in Mariée de force, Leila explains to author Marie-Thérèse Cuny how she survives a marriage that was forced on her by her father. Subjected to the same treatments Sibel and Malika have endured from their male counterparts, she does however fight back and through the legal system she will be able to find a way out of her desperate situation. In the conclusion of this remarkable true story, she manages to keep her son, the fount in which she finds the 
strength to live. An important characteristic sets Leila apart from Malika and Sibel. She is able to articulate clearly the problem that is inherent for the lives of second immigration Maghrebi girls who are born in France but who still have to abide by the rule of their tradition:

La famille est notre sécurité dans un monde que nous n'avons pas appris à dominer seules. Parce qu'ils nous refusent ce monde dès l'enfance. Et que nous y débarquons démunies, sans structure personnelle, conditionnées par les traditions, les interdits, la peur. Et aussi que nous aimons nos parents. Une fille maghrébine est quasiment incapable de couper le cordon. [...] Ce cordon ombilical nous étouffe, nous étrangle, jusqu'à la mort, même lorsqu'on est née en France (240-41).

[Our family is our security in a world which we have not learned to control by ourselves. Because from the moment we are born, they deny us this world. And we arrive there deprived, without any structure, conditioned by traditions, forbidden things and fear. And also we love our parents. For a Maghreb girl it is almost impossible to cut the cord. [...] This umbilical cord suffocates and strangles us until we die, even if we are born in France.]

Leila can identify and analyze the behaviors of other girls around her who in similar situations choose, on the surface, to abide by male edicts:

Quand je regarde les reportages sur ces filles qui veulent être voilées à l'école parce que c'est leur choix... j'ai vraiment des doutes. Certaines le font probablement pour récupérer une identité perdue. [...] Mais beaucoup 
se voilent, je le sais, simplement pour avoir la tranquilité, pour que les frères leur fichent la paix: "Ma soeur est voilée, c'est bon, je peux glander tranquille!" (Leila 200).

[When I look at reports about girls who want to wear their headscarf in class because it their own choice, I have my doubts. Some probably do it because they want to reclaim their lost identity. [...] But I know that many wear the veil so as to be left alone, so that their brothers leave them alone: "My sister wears the veil therefore, I can hang out without a worry."

For Malika and Sibel a compromise with a Western identity is a battle that they both want to win by going back to their roots. Sibel returns to Istanbul and Malika hopes to enter the university in Algeria. Leila sees alienation and rejects it. She does not want to accept a life in which even her body is not her own:

C'est le refus traditionnel de l'indépendance des femmes. C'est comme ça, et on n’a rien à dire. Il faut marcher droit, suivre le chemin tracé. Il n’y a pas d'évolution possible de mentalité. Cette virginité est sous la responsabilité du père ou des frères, puis du mari. Un corps de femme leur appartient (51).

[It is the traditional refusal of the independence for women. That's the way it is and there is nothing to say. One needs to walk straight, follow the beaten path. Changing the mind set is not possible. Virginity is under the responsibility of the father, brothers and, later, the husband. A woman's body belongs to them.] 
Leila's response is to learn to use the legal rights immigrants have in France and fight her way out of her predicament and indeed, she does succeed. Leila is not a literary writer. Her story is written by Marie-Thérèse Cuny, the "author" and it is published by J'ai Lu in the category "Document", a witness account as opposed to a novel. Though Leila is very apt at manipulating the legal system, art is not a way of life for her nor is it a tool of expression. In the next chapter, I will analyze authors who have turned their personal experiences into literary works. 
CHAPTER THREE:

\section{LIVING IN A HYBRID WORLD: LITERARY WOMEN SPEAK UP}

Through their own personal beliefs and experiences, immigrant women writers in both Germany and France can help other women redefine their own identities. They can overcome uncertainties and strive to create a better live for themselves. Through vivid descriptions of the difficulties and challenges women face, these writers make a positive contribution to the world of immigrant women. Some authors write in their native language and have their works translated into the language of their host country, while others write directly in the language of their new country. Saliha Scheinhardt and Leïla Sebbar, the authors whose writings I will examine, write respectively in German and in French.

Saliha Scheinhardt was born in Konya, Turkey in 1951 and came to Germany in 1967 where she first worked as a textile worker and cleaning lady. After being employed as a waitress and stewardess, she decided to study pedagogy in Göttingen where she received her doctorate in 1978 at the Pädagogische Hochschule. Her literary contributions give us an insight in the dilemma faced by Turkish women caught between patriarchal family structures and their new Western surroundings. Leïla Sebbar, a French-Algerian author who was brought up in an intellectual family, examines how Maghrebi immigrants must reach a compromise between their adoptive land and their once-colonized country. Her writings center more on second-and third-generation groups who fight to form their own identity in their hybrid cultural world. Both novelists face a multicultural environment where origins and race are challenged and where many new 
female settlers feel that they are living in exile. Through their parents and families, they have developed strong ties with their country of origin that are intertwined with the traditions of their adopted country. Through these experiences they contribute and write about the challenges first-and second-generation female immigrants encounter when they arrive or are born in a new homeland. The early writings of Saliha Scheinhardt address mostly how Turkish wives and daughters have no other choice than to follow their husbands or fathers to Germany. The literary writings of Leïla Sebbar will lead us into the world of second generations who are brought up in France and who have to find their own path in French society.

\section{A. The Faith of Female Turkish Immigrants in Germany Seen through Scheinhardt's}

\section{Writings.}

Azade Seyhan explains how Turkish women writers who immigrated to the West in the sixties and seventies did not arrive there as unskilled workers, but rather many were teachers and craftswomen. Many of them had no problem learning the German language and gained notoriety by putting their personal situations into writing (238). Their literary works are mostly biographical and highlight their cultural background and stories that they or other females experienced back home. Scheinhardt is very valuable as such a female author. She demonstrates through her publications that many immigrant women struggle not only because they are alienated but also because they suffer from a "culture shock". Seyhan comments that it is a "...double burden of the Turkish woman writer in Germany: to challenge her lowly status in her own culture and the negative images of her womanhood and ethnic identity in the host culture" (232). Scheinhardt's 
literary contributions describe the demanding situations immigrant women face when they arrive in their new homeland.

She embarked on her writing career in 1983 with Frauen, die sterben, ohne daß sie gelebt hätten [Women Who Die without Having Lived] and Drei Zypressen [Three Cypresses]. She speaks out for female minorities and narrates about persecution and discrimination they suffer not only from the society in which they live but also from the male family members whom they must follow to Germany. Scheinhardt's heroines experience this to an even greater extent in their newly adopted land. In addition to such novels, she has also composed political books on religious perspectives in Turkey and as well as in the diaspora. Her latest work, a short story, Töchter des Euphrat [Daughters of the Euphrates] (2005) is a work of fiction with poetic narratives. Heike Henderson describes Scheinhardt's literary contribution to the Islamic immigrant women cause as follows: "She graphically describes the situation of oppressed groups, usually minority women, and their search for a home. Her protagonists struggle to find a home in the country in which they live, and women especially also struggle to feel at home in their own families" (234).

In both of Scheinhardt's first two novels Frauen, die Sterben, ohne daß sie gelebt hätten and Drei Zypressen she approaches "[...] the plight of Turkish women caught between patriarchal Islamic family structures and an un welcoming foreign environment in Germany" (Henderson 235). The protagonists are first generation Turkish women who are forced to leave their homeland to follow either their fathers or husbands. They attempt to deal with living and working conditions that are degrading and oppressive. All of them share the same destiny of being brutalized by male family members and are 
oppressed by strict Islamic laws. Each of them stays in subordinate positions because of her tradition and her faith, but they will all find strength to survive and gradually become more independent.

In Drei Zypressen the three protagonists Gülnaz, Zümrüt, and Zeynep cope with male oppression while they have to adapt to a new western culture that is described as a cold foreign country: "Auf jeden Fall sind unsere Menschen nicht so kühl und unfreundlich wie die Deutschen" (30). [In any case our people are not as cold and unfriendly as the Germans]. All three must forsake their small villages in Turkey, since they leave the security and comfort of their families. They all hope for a better life in Germany but when they arrive there they realize that they are even more restricted than when they lived in Turkey: Gülnaz is forced to go to Germany because her father does not want her to repeat the same mistake as his other daughter, her eldest sister. She runs away from home for a man who was not chosen by her father: "In Deutschland wurde ich nicht mehr fliehen können, denn als noch Minderjährige war ich mit in den Paß meines Vaters eingetragen (20). [In Germany I would not able to flee anymore because as a minor I had been added in my father's passport]. On one of their summer vacations in Turkey she meets her husband, Yiğit, who joins his new wife and her father in Germany without a working permit. He ends up in jail for working illegally. Gülnaz's life becomes unbearable after she has her first child because she has to go back to work in order to support her family financially. In the Turkish tradition a man needs to sustain his wife and his family and not be supported: "Denn das hatte seinen männlichen Stolz besonders zerstört. Für einen türkischen Mann ist es das Schlimmste, was ihm passieren kann, finanziell von seiner Frau abhängig zu sein" (Z 50). [This had destroyed his male 
pride. For a Turkish man the worst thing that can happen is to be financially dependent on his wife]. She furthermore needs the help of her Turkish neighbors in order to have someone to watch her baby when she works.

Zümrüt moves to Germany with her father and his second wife at a very young age. While her father and his new wife go back to Turkey to deliver their baby, Zümrüt is left to manage on her own in a strange new country. She desperately tries to escape from Beşir, a Turkish neighbor who abused her sexually when she was eleven years old. She is not able to leave her house on her own because she fears for her own life: "Von diesem Tag an habe ich das Haus nicht mehr allein verlassen" [From that day on I never left the house anymore on my own]. She lives in constant fear: "Ich habe Angst vor Gewalt und Einsamkeit" (86). [I am afraid of violence and of loneliness]. Even when she marries Hakan, whom she loves, she is constantly harassed by Beşir who wants to have her as a second wife. Here Scheinhardt comments on polygamy: this man, who has a wife and children in Turkey, is obsessed with Zümrüt even though she herself is married and has a child. He never seems to be is satisfied and "Er wollte mich also zu seiner Frau machen" (98). [He wanted to take me as his second wife]. She attempts to kill him but does not succeed. After a long trial, the jury finds her emotionally unstable, and she thus avoids a prison sentence.

Zeynep is even more trapped because of her love for a German man called Werner. Since she came to Germany at the age of 4 she feels that she has no real homeland: "Ich habe keine Heimat. Ich bin nicht einmal in der Lage, ein sauberes Türkish zu sprechen. Meine Geschwister in der Türkei verstehen weder meine Sprache noch mein Benehmen, ich bin für sie ein Fremdling” (104). [I have no home. I am not 
even able to speak pure Turkish. My family in Turkey does not understand my language nor the way I behave. For them I am a foreigner]. Her cohabitation with a German man is a threat to her family's honor: "Die letzten Worte des Vaters seien gewesen: "Sie soll aus dieser Stadt verschwinden, es kann sein, daß, wenn sie uns über den Weg läuft, dies ihr Ende ist" (131). [The last words from her father apparently were: she has to disappear from this city because it will be the end of her if we saw her somewhere]. She is shunned by her family and they consider her an outcast.

As I already explained in Chapter One, honor for girls in the traditional Turkish family leads to many suicide attempts. Zeynep is unstable due to the fact that her own family has rejected her. Her life becomes even more unbearable when her German friend Werner tells her that he is not interested anymore in their relationship, and he leaves her. She tries to kill herself because she feels rejected by everyone she loves: "Die Selbstmordversuche unter türkischen Mädchen nähmen immer zu (132). [Supposedly suicide among Turkish girls is increasing].

Scheinhardt reminds the reader that all three protagonists have to cope with "living in two worlds" and that once they have left their native land - willingly or by force - they have no way to return even if they want to:

Es ist kein Wunder, daß wir Deutschlandtürken in unserer eigenen Heimat nicht sehr beliebt sind, es ist kein Wunder, wenn man uns in unserem eigenen Lande in die Augen lächlend verspottet, es ist kein Wunder, wenn sie uns hassen und uns das schwerverdiente Geld mit frecher Selbstverständlichkeit aus unseren Händen stehlen. Ja, unsere eigenen Leute ( Zypressen 38). 
[It is no wonder that we German-Turks are not loved in our own homeland, it is no wonder that they laughingly mock us directly to our faces; it is no wonder that they hate us and that they steal our hard-earned money from our hands with arrogance and self-righteousness even questioning it. Yes, our own people].

Some women become desperate and many of them try to murder their husbands, who have repeatedly beaten and sexually assaulted them. In the story of Suna in Frauen ,die sterben, ohne daß sie gelebt hätten, this theme is central to the life of this young woman whose marriage to a much older men was arranged and subsequently ruins her life. She tries to kill him after he forces her to have anal intercourse, which is strictly forbidden in the Islamic faith. Rob Burns comments that: "Suna's misfortune only begins when her husband starts to plague her with 'immoral desires' to which she refuses to accede in the knowledge that their Islamic faith strictly prohibits anal intercourse" (Bondage 344). She is convinced that her husband's behavior is the consequence of the new culture they live in: "Das Leben in Deutschland war ihm nicht gut bekommen. Er war außer Rand und Band. Die Freiheit und die Freizügigkeit der deutschen Frauen hatten ihn völlig verwirrt. [Life in Germany was not doing him good. He was going wild. The freedom and permissiveness that German women enjoyed bewildered him]. After Suna assaults him, she spends a long time in prison, forgotten by her family and children. Her husband wants her to be deported back to Turkey but, after realizing how she suffered under his sexually deviant desires, the court sets her free. She is reunited with her children and finds a job as a cleaning lady in order to survive in her new homeland. 
This story was first published in 1983 with a different ending. Suna is deported back to Turkey where she faces another trial and the wrath of her brother-in-law. In 1989 it was adapted into a movie by Tevfik Baser under the title "Abschied vom falschen Paradies" [Goodbye to a False Paradise]. Scheinhardt decided to publish a new edition of her book in 1991 with an upbeat ending (Burns, Images 753). The narrator insists on telling the reader that thanks to the good-hearted, well meaning Germans, Suna will be able to go back to her children. She will be able to lead the normal life she deserves. With this transformation toward a positive outcome Scheinhardt seeks to narrow the gap between the two cultures. She herself has been able to become successful in Germany and she wants other women to be able to integrate in a positive way into their new homeland.

The narratives of the four women illustrate how the themes of honor, male dominance, tradition and religion - discussed in the first chapter - are all intertwined. Scheinhardt is very sympathetic towards downtrodden females. She wants to find a solution for each of her characters. By keeping the stories simple she sends a message about how the traditional Turkish culture complicates the way that females behave when they live in two worlds. The reader can be engaged and made to understand better the lives of those immigrant women. Telling their stories gives them the possibility of coping with a complex hybrid world and to find a way out. This manner of getting her message across reminds us of the stories told in The Thousand and One Nights ${ }^{12}$ where

\footnotetext{
${ }^{12 ،}$ Many Turkish writers in Germany create their literary traditions not only from their cultural roots but also from literary communities they enter. This practice of writing liberates cultural production from the confines of a ghettoized ethnic aesthetic. In the stories of modern Turkish Scherazades, the semantic implication of the title The Thousand and One Nights - as infinity and one more - takes on concrete form as the boundless mobility and resilience of languages in dialogue". (Seyhan 247)
} 
Sheherazade unveils her tales to the sultan in order to survive. Although Scheinhardt's writings are neither exotic nor intricate she captures the reader's attention by sharing biographical stories. By using this kind of literary narrative she pinpoints how many Muslim immigrant women cope with the rules and traditions that they bring with them to their new unfamiliar world. Other political female writers, such as the Egyptian psychiatrist and female writer Nawal El Sadaawi, use their own personal stories to become more powerful and to overcome obstacles. Melissa Matthes explains:

... These women's memoirs are seeking to shape the popular living memory of their contemporary cultures. They are attempting to engage readers now in a struggle for narrative primacy and thus political transformation. These accounts invite us, through the power of their narrative dramas, to participate, to interpret and to judge the possibilities of living otherwise: these are texts as political action (69).

The main themes in Ausländerliteratur [foreign literature] - also called Gastarbeiterliteratur [guest-worker literature] - explored by authors are solidarity, a sense of belonging and identity in 'two worlds'. Foreign writers must go beyond those typical themes and must reconcile their German identity with a foreign background. In some instances one speaks about Brückenliteratur [bridge literature] because this kind of literature is a necessary link between Eastern and Western culture. In their writings, many female immigrants authors find common components so that they reach a better understanding of the two cultures.

Sarah Beth Tiede Buchanan points out how fictional narratives can mitigate cultural differences and how they can be perceived by imaginative power: "Narrative is a 
powerful weapon for combating hegemonic power structures. Because narrative creates identity and cultural codes, the imaginative power it has to invent new possibilities for collective identity can alter the perception of, that is to say, the reality of, social relationships" (27). This will become clear in the literary works of Leïla Sebbar, who feels that she is living in a hybrid world. Living in Paris with her family, she feels neither French nor Arabic, but rather she is a participant in both cultures.

\section{B. L. Sebbar's Writings: Algerian and French Influences Are Prevalent in her Literary}

$\underline{\text { Works. }}$

Born in Algeria, Leïla Sebbar spent her childhood with her family near Tlemcen where she lived until she was 19 years old. After living in Aix-en-Provence for two years she moved to Paris where she still lives with her family. She is the daughter of an Algerian father and a French mother. Her father was the director of a school where her mother worked as a teacher. Her parents had met each other when her father was doing an internship in Bordeaux, where her mother was studying. Living in a privileged and protected family, the author was brought up in a non-religious environment. Sebbar never mastered Arabic, her father's language, and her mother tongue is French. In an interview with Soheila Kian it becomes evident that Sebbar feels she is living in exile. She is divided between the two cultures that are very dear to her: "Coincée entre les deux univers elle se nomme une croisée, et décide de représenter la vie des immigrants maghrébins, aussi bien que le monde hybride des "Beurs," la seconde generations des immigrants maghrébins" (Kian 128). [Cornered between two worlds she calls herself a cross between two cultures." She decides to represent the life of Maghrebi immigrants, 
as well as the hybrid world of the "Beurs" the second generation of the Maghrebi immigrants]. For Françoise Lionnet, the writings from authors such as Sebbar contribute greatly to re-thinking the classification of French literature:

Through her use of the themes of exile, deracination, loss of memory, silence, and revolt, Sebbar belongs to the lineage of "francophone" writers who have risen up against the "civilizing mission" of France in Africa and elsewhere. But her original contribution is to have made immigrant women - doubly marginalized by their womanhood and their Arab background - the very center of a work that problematizes the entire visual and discursive tradition of European Orientalism (66).

Leïla Sebbar made her literary debut in French Literature with a novel trilogy: Shérazade: Shérazade, dix-sept ans, brune, frisée, les yeux verts (1982), Les carnets de Shérazade (1985) and Le fou de Shérazade (1991). When Kian asks why Sebbar uses the name Shérazade her answer distinguishes her from an autobiographical writer, who merely retells her experience in transparent words. Leïla Sebbar inscribes her trilogy in European and Middle- Eastern literary traditions. Sebbar pointedly remarks that, like her, part of Shérazade is lost in translation: "Shérazade a perdu une syllable en passant d'Orient en Occident." [Shérazade has lost a syllable when going from East to West]. She elaborates further on the same theme: "Shérazade est ma petite soeur de papier, ma complice. Je suis proche d'elle aussi parce qu'elle est comme moi divisée entre Algérie et France, à la recherché d'elle ne sait quoi, je me découvre aussi avec elle" (Kian 132). [Shérazade is my little sister in writing, my accomplice. I am very close to her because she is like me, divided between Algeria and France. She is searching for she knows not 
what and I reveal myself when I am with her]. Clearly she wants to find a balance between Eastern and Western cultures. The themes discussed in Chapter I are also present in Sebbar's works, although she often inscribes them in a very different context than autobiographical writers. For example, in one of her short stories, "Le Baiser" [The Kiss] she writes about the veil as a source of comfort and material love rather than a political weapon. The motifs of Islam serve to convey universal feelings of love:

Sous le linge intime de son tiroir, le deuxième, elle range ses foulards islamiques, c'est elle qui les lave et qui les repasse. Les couleurs qu'elle préfère: le bleu, le vert, le blanc. En voile de coton doux et léger. Après la prière du matin, c'est le temps du hijeb. Elle s'enferme dans la salle de bains et n'entend pas les frères qui frappent de plus en plus fort à la porte, malgré les protestations de la mère qui prépare les petits. C'est son temps. C'est sacré (Le Baiser 28).

[Under the lingerie in her second drawer, she keeps her Islamic scarves. It is she who washes and irons them. Her preferred colors are blue, green and white. Airy and soft cotton muslin. After morning prayers, it is time for the hijab. In spite of her mother's protests while preparing the little ones, she locks herself in the bathroom, oblivious to her brothers who knock more and more insistently on the door. It is her time. It is sacred].

This passage occurs verbatim six years later in another story entitled "la fille au hijeb"(84) in the collection of short stories called Sept filles. This clearly shows that the Islamic rituals are part of Sebbar's upbringing. Her feeling of belonging is not only to 
her French but also to her Arabic heritage. Both are part of her and for her writing about it is therapeutic.

According to Dana Strand, most of Sebbar's writings intertwine her personal life stories and the unsettling lives of Maghrebi immigrant women in France: "Motivated no doubt by her own personal experience, Leila Sebbar has made the politically-charged intersection between geography and identity a central issue in the novels and short fiction she has written over the past fifteen or twenty years" (160). Madeleine Van StrienChardonneau even goes further by stating that Sebbar is the one of the leading voices to explain the problems of those women:

L. Sebbar nous fait entendre les voix de ces immigrés, celles des femmes surtout, ces Algériennes qui se réunissent au square pour y garder leurs enfants et bavarder entre elles des difficultés de la vie quotidienne en même temps qu'elles évoquent le pays d'origine: La France est sans aucun doute le pays de l'exil, le Maghreb le lieu d'appartenance (26).

[L. Sebbar lets us hear the voice of immigrants, especially the women: those Algerian women who meet each other at the square where they take care of their children. They talk about their everyday problems and at the same time they recollect their motherland. France is without a doubt the country of exile and the Maghreb is where they belong].

Sebbar has recourse to various means to express her own feelings of exile and hybridity. One of those venues is correspondence with a Canadian writer, Nancy Huston. Both women live in Paris with their children and write letters in French to each other in Lettres parisiennes: Autopsie de l'exil. Although their backgrounds are different they 
find common ground. Patrice Proulx comments: "Huston and Sebbar work together to elicit the problematic situation of crossing borders - whether they be geographic, or psychological - and make manifest the trangressive nature (especially for women) of living in an Other culture" (80). Both authors use writing as a therapy to overcome these emotions of not belonging: “...l'exil me reprend dès que je n'ai pas un stylo en main...” (Lettres 177) [...my exile starts the moment I do not have the pen in my hands...]. In several of her letters Sebbar repeatedly brings up the themes of exile $(31,50,112,120$, 126) and living in a hybrid life $(20,55,60,124,165)$. Her own explanation and her reason for her status as a croisé is best portrayed when she writes Nancy Huston:

[...] mon père arabe, ma mère française; mon père musulman, ma mère chrétienne; mon père citadin d'une ville maritime, ma mère terrienne de l'intérieur de la France....Je me tiens au croisement, en déséquilibre constant, par peur de la folie et du reniement si je suis de ce côté-ci ou de ce côté-là. Alors je suis au bord de chacun de ces bords. [...] (185). [...My Arab father, my French mother ; my Muslim father, my Christian mother; my father who comes from a coastal city, my mother a country woman from France.... I stand at the crossroads constantly unbalanced, out of madness and repudiation by either part. Because of this, I am on the border of each of these borders...]

Thanks to her literary writings Sebbar can overcome her own feelings of not belonging to any particular culture, but she accepts her plight. This gives her the understanding to fight for recognition of female immigrants. She continues to explain why she feels that she is not an immigrant herself: “je ne suis pas immigrée, ni enfant de l'immigration... Je 
ne suis pas un écrivain maghrébin d'expression française... Je ne suis pas une Française de souche... Ma langue maternelle n'est pas l'arabe..."(125). [I am not an immigrant, not a second-generation immigrant... I am not a Maghrebi writer who expresses herself in French... I am not a native French speaker... My mother tongue is not Arab....] Her statements show her own confusion and feeling of not belonging and does not locate her in a specific group; this is what makes her unique.

Scheinhardt and Sebbar are positive influences for immigrant women both in Germany and France and through their own experiences that they put into writing, they give more courage to a group of immigrants who are often ignored and forgotten. 


\section{CONCLUSION}

Globalization and integration are two concepts that are inherent to modern Western European society. The openness created by the European Community generates multiple foci on cultural identities. The lines between nationalities and cultures are blurred. Winifred Woodhull comments: "In an age of racism without races, the cultural work of reconfiguring ethnicity is crucial, and it is inseparable from struggles for equal rights and economic justice" (59). Racism in Germany and France had been dormant for two decades, since immigrant laborers were desperately needed. After the Berlin Wall fell, the labor market shifted drastically, changing the reality of racism. Xenophobia toward Muslim immigrants is stronger than ever now. The currant layout of urban geography, where ghettos isolate immigrants, has become a normal feature of European cities.

This new situation was nowhere better exemplified than during the November 2005 riots in France and in neighboring countries. The violence was not claimed by any specific radical Islamic organization. Indeed, many Muslim associations condemned the riots and patrolled the streets in order to stop the fires and car burnings. In Clichy-sousBois, the Paris suburb where the unrest started, violence flared up because immigrants revolted against police discrimination. However, the events soon spread to communities all over France, where police brutality was not necessarily at the core of the unrest. What the various rioting cities had in common though, was that all the immigrant communities touched where located in low-income, high-rise buildings where no sense of community exists. I have mentioned the HLM's - Chapter Two (25) - which are the government subsidized apartments in the banlieues [suburbs]. These are exactly the settings for those 
riots. Nevertheless, attentive observers though have been warning the public for years, as is evident in the works of various artists. In the wake of the tumult, Alan Riding commented in The New York Times:

So life often imitates art. Yet with the recent uprisings in some French immigrant neighborhoods, this cliche came with a new twist: art, in the form of movies and rap music, has long been warning that French-born Arabs and black youth felt increasingly alienated from French society and that their communities were ripe for explosion (B1).

For Riding, the best example of this is Mathieu Kassovitz's 1995 movie, La Haine, [Hate] that showed the problems of Arab and African immigrants he calls the "lost generation." Riding further comments that this surge of films and literature showing how immigrants cope with their everyday life is part of the artistic life not only in France but also in Germany and the Netherlands (7).

Interestingly, the media have focused exclusively on the young male immigrants brought into the public spotlight, while women remained invisible. Again, the opinion of Muslim women was neglected and ignored. If this study can contribute anything to the topic of new identities, it is clear though that the female Muslim community should receive the attention it desperately needs and deserves. As I have argued before, there is a gradual change in the way immigrant women's rights are being perceived.

Increasingly younger Muslim women, both in Germany and France, are attaining better levels of education. They are gradually integrating the workforce as better-skilled workers. These transformations are seen not only in the workplace, but also in the public space of politics and Muslim activism. More women are active in the election process, 
either as voters or as successful candidates. On the religious and cultural scene, women are also gaining preeminence in the Muslims regional councils. Hanife Karakus for example, is the first woman being chosen as president of the Council in Limoges, France. Siegfried Forster writes about her that "She is a woman that unites many different things in her personality: tradition and modernity, emancipation and heritage, mother and politician, mosque and internet, homeland and foreign parts, Muslim and Frenchwoman" (3). Those characteristics are indeed the core of the way women can find their own identity in their new established homelands.

Political leaders should focus their attention on younger Muslims, both male and female, since they will play an essential in role in bringing together the Eastern and Western worlds. Schmidt explains the fundamental difference between East and West. Individualism is the cornerstone of Western society. On the other hand, Muslim society is built on communities and families, a world that is usually portrayed in the West as oldfashioned, in particular with regard to its restricting laws for women. It is true that tradition is a quintessential part of Muslim society but it does not necessarily have to stand in the way of one's own individuality. Young second-or third-generation Muslim immigrants are trying to find their own path by gaining knowledge about Islam through books, scholarly work and increasingly through networking on the Internet. The fact that their Islamic heritage has been passed down from generation to generation does not automatically mean anymore that the youth will follow this religion. If they opt for the Islamic religion themselves, it will be a conscious choice. Young Muslims believe that their religion is adaptable to the ideals of Western democracies (Schmidt 35-36). Schmidt concludes that we need to give the younger generation more attention: "This is 
mainly because of their enthusiasm, their activism and their visibility; and perhaps of their eagerness to prove that Islamic and Western ideals are not contradictory; and because the activities of the young are prime examples of Muslim social integration in Western contexts" (38). Since young immigrants experience feeling of hybridity, it is imperative that they find their own identity and indeed, many find it back in their Muslim faith. The new term being coined, "Euro-Muslims" illustrates the challenge that young males and females, descendants of the Beurs and Gastarbeiter, face to adapt their fundamental values to modern Europe.

The literary works and the film that were discussed in Chapter Two and Three clearly indicate that the lives of female immigrants are continuously being challenged. In 2004, the murder of Dutch film maker Theo Van Gogh by a Muslim fanatic shocked the traditionally liberal Dutch society. As Hirshi Ali's collaborator on the movie Submission, he was working on a graphic demonstration of Islamic oppression of women. This crime highlights the paradox of the oppression of Muslim women, since speaking out on behalf of the oppressed can bring more harm to them as in retaliation. After Van Gogh's death, rage and fear roared in the Netherlands within the autochthonous communities and the Muslim communities for several weeks.

Politician figure Hirshi Ali, co-producer of the movie, is a Dutch legislator who was brought up in a Somali Muslim family. She has been an outspoken supporter of women's rights in Dutch Muslim society. Deborah Scroggins points out that Ali has many critics, not only in Muslim society but also within feminist groups. She depicts Islam in such a negative way that as a result of the image she propagates, many Muslim women in the Netherlands are being kept under even closer surveillance and are using the 
veil again. Women's rights activist and second-generation Moroccan immigrant Miriyam Aouragh says: "She has never fought for the oppressed. In fact, she's done the opposite. She uses these problems as a cover to attack Islam. She insults me and she makes my life as a feminist ten times harder because she forces me to be associated with anti-Muslim attacks" (Scroggins 24). Hirshi Ali is perhaps too critical toward Islam, but she is an example of how individuals are standing up for their cause.

Groups such as Ni putes ni soumises (see Chapter One, 11) help young French Muslim women and girls who are trapped to find shelter against male abuse. Seyran Ates, a Berlin-based lawyer, is suing the German government for its lack of timely intervention in cases of honor killing (Chapter One, 12; Scroggings 24). All over Europe, movements for women's rights are cropping up, and this can only mean hope for the future.

Being myself an immigrant from Western Europe living in the United States for the last twenty years, I can only testify that living in an "other" world is a long process of adaptation. It takes years before one begins to have a sense of belonging in the new homeland. During the course of my research, I was often able to identify with Muslim immigrant women regarding the problems of assimilation, especially those related to finding one's own identity in a new world. I realize that there is a fundamental difference between my experiences coming to the United States and that of immigrant Muslim women in Germany or France: I moved from a Western country to another Western country, where values are similar. My family moved for educational purposes.

Financial, racial and religious matters were never an issue, whereas they are of primary importance to the female Muslim immigrants I have studied. They have to adapt from an 
Eastern into a Western World. Their religion has so many traditions that often have negative repercussions in a Western society. The process of assimilation for Muslim female immigrants is a long and winding road, but with endurance and help from politicians and women right's groups, it can be made a less painful path. 


\section{WORKS CITED}

Adelson, Leslie A. “Migrants' Literature or German Literature? Torkan's Tufan: Brief an einen islamischen Bruder." Writing New Identities: Gender, Nation and Immigration in Contemporary Europe. Ed. Gisela Brinker-Gabler and Sidonie Smith. Minneapolis : U of Minnesota, 1997: 216-29.

Almosaed, Nora. "Violence Against Women: A Cross-cultural Perspective." Journal of Muslim Affairs 24, No 1, (2004): 67-88.

Badawi, Jamal A. "The Status of Women in Islam.” Islam for Today. April 1980 $<$ http://www.islamfortoday.com/womensrightbadawi.htm $>$.

Bellil, Samira.. Dans l'enfer des tournantes. Éditions Denoël, Mesnil-sur-l'Estrée, France, 2003.

Brinker-Gabler, Gisela and Sidonie Smith, ed. Writing New Identities: Gender, Nation and Immigration in Contemporary Europe. U of Minnesota, 1997.

Burns, Rob. "From Bondage to Bonding: Saliha Scheinhardt: Frauen, die Sterben, ohne dass sie gelebt hätten and Tevfik Baser: Abschied vom falschen Paradies." Text Into Image: Image Into Text. Ed. Jeff Morrison and Florian Krobb. Amsterdam: Rodopi, 1997: 339-47.

—. "Images of Alterity: Second-Generation Turks in the Federal Republic." Modern Language Review 94 (1999): 745-57.

Dayan-Herzbrun, Sonia. "The Issue of the Islamic Headscarf." Women, Immigration and Identities in France. Ed. Carrie Tarr and Jane Freedman. New York, 2000: 69-82.

De Raedt, Therese. "Muslims in Belgium: A Case Study of Emerging Identities." Journal of Muslim Affairs 24, No 1, (2004): 9-30.

Dumeige, Valerie and Ponchelet, Sophie. Françaises. Paris, NiL éditions, 1999.

Durlemat, Sylvie. "L'invention de la 'Culture Beur'." Dissertation U of Michigan, 1997.

Edmiston, William F. and Annie Duménil. La France Contemporaine. Boston, Mass: Thomson Heinle, 2005.

"Ehrenmord in Berlin.” Raumzeit March 2005. < $\underline{\text { http://www.raumzeit-online.de> }}$

Fennell, Barbara A. Language, Literature, and the Negotiation of Identity: Foreign 
Worker German in the Federal Republic of Germany. Chapel Hill: $U$ of North Carolina, 1997.

Foster, Siegfried. "I see Myself as a Muslim Frenchwoman: Portrait of Hanife Karakus." Deutsche Welle. 08.02.2006

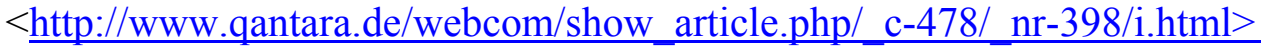

Gafaiti, Hafid (ed.). "Cultures et transnationalité." Cultures transnationales de France des "Beurs" aux...? Paris, France: Harmattan (2001): 9-24.

Gegen die Wand. Dir. Fatih Akin. Perf. Sibel Kekeli and Birol Ünel , 2004.

Giddens, Anthony. "Beneath the Hijab: a Woman." New Perspectives Quaterly 21 No 2 (Spring 2004): 9-11.

Gozlan, Martine. “La bataille du voile.” Marianne: 5 - 11 Janvier, 2004: 14-17.

Graupner, Hardy. "German Citizens face Expatriation.” Deutsche Welle February 2005 $<$ http://qantara.de $>$

Hamm, Horst. Fremdgegangen - freigeschrieben; eine Einführung in die deutschsprachige Gastarbeiterliteratur. Würzburg: Königshausen und Neumann, 1988.

Hargreaves, Alec G. "Une culture innommable?". Cultures transnationales de France des "Beurs" aux...?. Ed. Gafaiti, Hafid. Paris, France: Harmattan: 2001: 27-36.

Henderson, Heike. "Re-Thinking and Re-Writing Heimat: Turkish Women Writers in Germany." Women in German Yearbook 13 (1997): 227-43.

Hummel, Thomas. “'Ich muss Deutsch lernen!'. Wie Frauen aus Griechenland und der Türkei, Russland und Chile die Sprache ihrer neuen Heimat lernen." Kulturjournal des Goethe-Instituts 1/05: 26-29.

Kessars, Ferrudja. Beur's story. Paris: L’Harmattan, 1994.

Kian, Soheila. "Une Entrevue avec Leïla Sebbar: L'écriture et l'altérité." The French Review 78, No 1 (2004): 127-136.

Knapper, Bridget. "Beur FM, agent of Integration of ghetoisation?" $<$ http://wjfms.ncl.ac.uk/KnapperWJ.htm $>$ 4/8/2005.

Leila. Mariée de force. With the collaboration of Marie-Thérèse Cuny. Paris: Editions J'ai Lu, 2004. 
"Learning About Mohammed and the Koran in German." DW Online 19 Aug. 2003.12 Sept. $2003<$ http://www.qantara.de/webcom/show article.php/ c-478/ nr$\underline{\text { 22/i.html }>}$

Levieux, Eleanor \& Michel Levieux. Insiders' French: Beyond the Dictionary. Chicago: U. Of Chicago Press, 1999.

Lionet, Françoise. "Narrative Strategies and Postcolonial Identity in Contemporary France Leïla Sebbar's Les Carnets de Shérazade." Writing New Identities: Gender, Nation and Immigration in Contemporary Europe. Ed. Gisela BrinkerGabler and Sidonie Smith. Minneapolis : U of Minnesota, 1997: 62-77.

Martin, Richard C. Encyclopedia of Islam and the Muslim World. 2004 ed. (330).

Matthes, Melissa. "Shahrazad's Sisters: Storytelling and Politics in the Memoirs of Mernissi, El Saadawi and Ashrawi.” Journal of Comparative Poetics Alif, 1999 (19).

Minces, Juliette. The House of Obedience. London: Zed Press, 1982.

Naggar, Mona and Jennifer Taylor-Qaida (translator). "A Meeting Place for Women from Different Countries." Qantara.de $2003<$ http://www.qantara.de>

Nationmaster.com $<\underline{\text { http://www.nationmaster.com/encyclopedia/Islamism }>}$

Novariantoni, "Interview on Islam and Secularism with Soheib Bencheikh.” Liberal Islam Network: April 2004.

<http://www.Qantara.de/webcom/show_article.php_/c-478/_nr-130/i.html>

Pfaff, Carol W. "Sociolinguistic Problems of Immigrants: Foreign Workers and their Children in Germany." Language in Society 10 (1981): 155-88.

Presidency of Islamic Researchers, IFTA, editors and translators. The Holy Qur'an, English Translation of the meanings and Commentary 1992.

Proulx, Patrice J. "Writing Home: Explorations of Exile and Cultural Hybridity in the Correspondence of Nancy Huston and Leïla Sebbar." L'Esprit Créateur XL, No 4 (2000): 80-88.

Riding, Alan. "In France, Artists Have Sounded the Warning Bells for Years". The New York Times, Thursday, November 24, 2005: B1,7.

Ripperger, Sabine. "On Headscarves and Lawcourts." Qantara.de Dialogue with the Islamic World 2003 Deutsche Welle. 12 Sept. 2003.

$<$ http://www.qantara.de/webcom/show_article.php/_c-478/_nr-16/i.html>. 
Saadawi, Nawal El. The Nawal El Saadawi Reader. New York: St. Martin's Press, 1997.

_. A daughter of Isis: The Autobiography of Nawal El Sadaawi. London \& NY: Zed Books, 1999.

Sabra, Martina. "Working Together against Legal Discrimination and Male Violence ." Qantara.de Dialogue with the Islamic World 2003. 12 Sept. 2003. $<$ http://www.qantara.de/webcom/show_article.php/_c-478/_nr-21/i.html>.

"Samira Bellil, 31, French Muslim Who Wrote her Gang Rape". The New York Times Obituaries. Friday, September 10, 2004.

Scheinhardt, Saliha. Drei Zypressen: Erzählungen über türkische Frauen in Deutschland. Freiburg: Herder Spektrum, 1992.

—. Frauen, die sterben, ohne dass sie gelebt hätten. Freiburg: Herder Spektrum, 1993.

Schmidt, Garbi. "Islamic Identity Formation among Young Muslims: The Case of Denmark, Sweden and the United States." Journal of Muslim Affairs 24, No 1, (2004): 31-45.

Scroggins, Deborah. “The Dutch-Muslim Culture War.” The Nation June 27, 2005: 2125.

Sebbar, Leïla. Le baiser. Paris: Hachette jeunesse, 1997.

—. Lettres Parisiennes: Autopsie de l'exil. Paris: Barrault, 1986.

_. Sept filles. N.p. Editions Thierry Magnier, 2003.

Şen, Faruk. "Forty Years Later: Turkish Immigrants in Germany." Deutsche Welle Spring 2002: 28-35. <DW-World.de $>$

Seyhan, Azade. "Scheherazade's Daughters: The Thousand and One Tales of TurkishGerman Women Writers." Writing New Identities: Gender, Nation and Immigration in Contemporary Europe. Ed. Gisela Brinker-Gabler and Sidonie Smith. Minneapolis : U of Minnesota, 1997: 231-4.

Shteiwi, Musa. "Arab Women, the Internet and Public Space." Qantara.de Dialogue with the Islamic World 29 July 2003. 12 Sept. 2003

$<$ http://www.qantara.de/webcom/show_article.php/_c-478/_nr-18/i.html>. 
Talahite, Anissa. "Identity as "Secret de Guerre": Rewriting Ethnicity and Culture in "Beur" Literature." Cultures transnationales de France des "Beurs" aux...? Paris, France: Harmattan: 2001: 55-64.

Tiede Buchanan, Sarah Beth. "Inside, Outside and Inside-Out, Gender and Nationalism in French Immigration Literature and Film.” Dissertation U of Minnesota, 2000.

Tietze, Nikola. 'L'Islam turc de la diaspora en Allemagne: La Force des communautés imaginées." Cahiers d'études sur la Méditerrannée orientale et le monde turcoiranien 30 (juin-décembre 2000): 253-69.

Topçu, Canan. "Female Muslims in Germany: The Multiple Worlds of Turkish Women." Qantara.de Dialogue with the Islamic World 17 May 2005.

<http://www.qantara.de/webcom/show article.php/ c-478/ nr-276/i.html>

Van Strien-Chardonneau, Madeleine. "De la Quête d'une patrie à la découverte de l'écriture: Les Enfants de l'immigration dans deux romans de Leïla Sebbar." Ed. De Ruyter-Tognotti: L'étranger dans la littérature française. Cahiers de recherches interuniversitaires néerlandaises 20 (1989): 26-54.

Waddy, Charis. The Muslim Mind. New York: Longman Group Limited, 1982.

Woodhull, Winifred. "Ethnicity on the French Frontier." Writing New Identities: Gender, Nation and Immigration in Contemporary Europe. Ed. Gisela BrinkerGabler and Sidonie Smith. Minneapolis : U of Minnesota, 1997: 216-29.

Yalçin-Heckmann, Lale. "Negotiating Identities: Media Representations of Different Generations of Turkish Migrants in Germany." Fragments of Culture: The Everyday of Modern Turkey. Ed. Deniz Kandiayoti \& Ayşe Saktauber. New Brunswick: Rutgers 2002: 308-19. 